Original Article

\title{
Curcumin Inhibits Cell Proliferation, Stimulates Apoptosis and Down-Regulates Aldehyde Dehydrogenase Expresion in Gastric cancer Cell line MKN45
}

\author{
Nguyen Phu Hung ${ }^{1, *}$, Le Thi Thanh Huong ${ }^{1}$, Nguyen Trung Thanh ${ }^{2}$ \\ ${ }^{I}$ Thai Nguyen University of Sciences, Thai Nguyen University \\ Z115 street, Tan Thinh ward, Thai Nguyen city, Thai Nguyen province, Vietnam \\ ${ }^{2}$ VNU University of Science, 334 Nguyen Trai, Hanoi, Vietnam
}

Received 10 May 2020

Revised 28 August 2020; Accepted 30 August 2020

\begin{abstract}
According to estimates by the World Health Organization (WHO), in 2018 there were over one million new stomach cancer patients. Vietnam ranks the tenth among the countries with the highest rates of stomach cancer in the world, with the rate of 15.9 cases per 100,000 populations. Research on compounds or drugs that can inhibit cancer cell growth but are less toxic to the body is necessary. In this study, using MTT assays, we have shown that curcumin has ability to inhibit proliferation of stomach cancer cells MKN45. Flow cytometry analysis showed that curcumin increased the percentage of apoptosis cells by $27-56 \%$ at concentrations of $10 \mu \mathrm{M}-20 \mu \mathrm{M}$ and resulted in a typical nuclear morphology of apoptosis. Further, this study showed that curcumin significantly reduced the expression of aldehyde dehydrogenase protein in MKN45 gastric cancer cells. This finding shows that curcumin is a potential therapeutic candidate for gastric cancer cell treatment.
\end{abstract}

Keywords: curcumin, gastric cancer stem cell, cancer stem cell marker, aldehyde dehydrogenase.

\footnotetext{
* Corresponding author.

Email address: hungnguyenphu@tnus.edu.vn

https://doi.org/10.25073/2588-1140/vnunst.5076
} 


\title{
Curcumin ức chế sự tăng sinh, cảm ứng apoptosis và làm giảm sự biểu hiện của aldehyde dehydrogenase ở tế bào ung thư dạ dày MKN45
}

\author{
Nguyễn Phú Hùng ${ }^{1, *}$, Lê Thị Thanh Hương ${ }^{1}$, Nguyễn Trung Thành ${ }^{2}$ \\ ${ }^{1}$ Truò̀ng Đại học Khoa học, Đại học Thái Nguyên, đưòng Z115, phuò̀ng Tân Thịnh, thành phố Thái Nguyên, \\ tỉnh Thái Nguyên, Việt Nam \\ ${ }^{2}$ Truoòng Đại học Khoa học Tự nhiên, 334 Nguyến Trãi, Hà Nội, Việt Nam
}

Nhận ngày 10 tháng 5 năm 2020

Chỉnh sửa ngày 28 tháng 8 năm 2020; Chấp nhận đăng ngày 30 tháng 8 năm 2020

\begin{abstract}
Tóm tắt: Theo ước tính của Tổ chức Y tế Thế giới (WHO), trong năm 2018 có trên một triệu bệnh nhân ung thư dạ dày mới. Việt Nam xếp thứ 10 trong số các quốc gia có tỉ lệ ung thư dạ dày nhiều nhất thế giới với tỉ lệ 15,9 ca mắc ung thư dạ dày trong 100.000 dân số. Nghiên cứu các hợp chất, các thuốc có khả năng kìm hãm sự phát triển của tế bào ung thư nhưng ít độc hại cho cơ thể là rất cần thiết. Trong nghiên cứu này, bằng phân tích sự tăng sinh tế bào (MTT), chúng tôi đã chỉ ra rằng curcumin có khả năng ức chế rõ rệt sự tăng sinh của tể bào ung thư dạ dày MKN45. Các phân tích bằng Flow cytometry cho thấy rằng, curcumin đã làm tăng tỷ lệ \% tế bào apoptosis từ $27 \%$ đến $56 \%$ ở các nồng độ từ $10 \mu \mathrm{M}-20 \mu \mathrm{M}$ và làm xuất hiệu kiểu nhân điển hình của tế bào apoptosis. Xa hơn nữa, nghiên cứu này đã chỉ ra rằng, curcumin đã điều hòa giảm sự biểu hiện của protein aldehyde dehydrogenase trong tế bào ung thư dạ dày MKN45. Kết quả này cho thấy curcumin là một chất tiềm năng cho việc xử lý tế bào ung thư dạ dày.
\end{abstract}

Tù khóa: curcumin, tế bào gốc ung thư dạ dày, marker tế bào gốc ung thư, aldehyde dehydrogenase.

\section{Mở đầu}

Theo thống kê của Cơ quan nghiên cứu ung thư quốc tế năm 2018 (Globocan, 2018), tỷ lệ mắc và chết bởi ung thư dạ dày ở Việt Nam chỉ đứng thứ 3 sau ung thư gan và ung thư phổi, với khoảng 17 nghìn trường hợp mắc mới và 15 nghìn trường hợp tử vong được ghi nhận [1]. Hóa trị liệu là một trong những phương pháp chủ chốt trong điều trị ung thư nói chung và ung thư dạ dày nói riêng. Tuy nhiên, các thuốc chống ung thư có nguồn gốc tổng hợp hóa học đang sử dụng trong điều trị hiện nay thường gây ra những tác dụng không mong muốn lên chức năng của các

\footnotetext{
* Tác giả liên hệ.

Địa chi email: hungnguyenphu@tnus.edu.vn
}

https://doi.org/10.25073/2588-1140/vnunst.5076 cơ quan khác nhau trong cơ thể, ảnh hưởng đến sức khỏe của người bệnh. Trong những năm gần đây, việc tìm kiếm, thử nghiệm phát triển các thuốc mới có nguồn gốc từ tự nhiên để sử dụng trong điều trị ung thư nói chung và ung thư dạ dày nói riêng đang được quan tâm [2].

Curcumin thuộc nhóm polyphenol được phân lập lần dầu tiên từ cây Nghệ (Curcuma longa) năm 1815. Curcumin đã được chỉ ra trong các nghiên cứu khác nhau như là một hợp chất có nhiều hoạt tính sinh học quan trọng. Trong lâm sàng, curcumin được sử dụng để điều trị nhiều bệnh mãn tính như viêm, viêm khớp, hội chứng chuyển hóa, bệnh gan, béo phì, bệnh thoái 
hóa thần kinh. Đặc biệt quan trọng, curcumin đã được chứng minh là có khả năng ức chế sự phát triển của nhiều loại ung thư khác nhau [3]. Trong trường hợp của ung thư vú, curcumin được chỉ ra là ức chế các tế bào ung thư thông qua cơ chế ức chế sự biểu hiện của thụ thể của yếu tố tăng trưởng biểu mô (HER2), thụ thể này đóng vai trò quan trọng đối với sự phân chia của tế bào ung thư vú [4]. Curcumin cũng được chứng minh là thúc đẩy quá trình apoptosis đối với tế bào ung thư phổi thông qua cơ chế ngăn chặn sự biểu hiện của COX-2, EGFR [5]. Trước đó, một nghiên cứu của Yang và cộng sự [6]đã cho thấy rằng, curcumin đã cảm ứng quá trình apoptosis ở các tế bào ung thư bạch cầu mono cấp tính bằng cơ chế hoạt hóa con đường tín hiệu JNK/ERK.

Đối với ung thư đường tiêu hóa, curcumin đã được chỉ ra là một tác nhân gây ức chế sự tăng sinh tế bào, làm dừng chu kỳ tế bào và cảm ứng quá trình apoptosis ở một số dòng tế bào ung thư đại tràng như HCT116 và HT29. Cơ chế của sự ức chế cũng đã xác định là do curcumin đã điều hòa giảm sự biểu hiện của hexokinase II, loại bỏ phân tử này ra khỏi ty thể và dẫn tới quá trình apoptosis trung gian qua ty thể [7]. Trong trường hợp của ung thư dạ dày, nhiều nghiên cứu khác nhau đã cho thấy curcumin có khả năng kìm hãm sự phân chia và tăng cường quá trình apoptosis thông qua nhiều cơ chế phân tử khác nhau như hoạt hóa protein caspase 3 , caspase 8 , Bax hay ức chế sự biểu hiện của gene mã hóa cycline D1 và Bcl-2 [8]. Mặc dù, một số cơ chế phân tử giải thích cho khả năng ức chế của curcumin đối với tế bào ung thư nói chung và ung thư dạ dày nói riêng đã được nghiên cứu, nhưng có thể thấy rằng, curcumin có khả năng tác động đồng thời lên nhiều đích khác nhau trong tế bào ung thư dạ dày. Trong một nghiên cứu của Liu và cộng sự trên dòng tế bào ung thư dạ dày SGC-7901, curcumin đã ức chế sự tăng sinh tế bào bằng cách điều hòa giảm con đường tín hiệu c-Myc/H19 mà ở đó, H19 là phân tử RNA không mã hóa, kích thước lớn [9]. Một nghiên cứu khác của Zheng và cộng sự lại cho thấy rằng, đích tác động của curcumin lên dòng tế bào ung thư dạ dày AGS, SNU1 và SNU5 lại là con đường tín hiệu $\mathrm{Wnt} / \beta$ Catenin [10]. Trong nghiên cứu của Zheng và cộng sự đã chỉ ra rằng, curcumin đã điều hòa giảm sự biểu hiện của các protein Wnt3a, $\beta$ Catenin, c-myc dẫn tới ức chế sự tăng sinh tế bào và tăng cường quá trình apoptosis của tế bào [10]. Aldehyde dehydrogenase được biết đến là một protein enzyme có vai trò quan trọng trong việc loại bỏ độc tố và ngăn cản quá trình apoptosis của tế bào [11]. Đối với ung thư dạ dày, việc tác động của curcumin lên sự biểu hiện của $\mathrm{ALDH}$ với sự tăng sinh và apoptosis của tế bào còn chưa được làm sáng tỏ.

\section{Vật liệu và phương pháp nghiên cứu}

\subsection{Vật liệu, hóa chất}

Dòng tế bào ung thư dạ dày (MKN45) được sử dụng trong nghiên cứu này được cung cấp bởi phòng thí nghiệm Inserm U1053 thuộc Viện Sức khỏe và Nghiên cứu Y học Quốc gia, Đại học Bordeaux, Cộng hòa Pháp. Curcumin do Sigma Aldrich (Pháp) cung cấp có nguồn gốc từ cây Nghệ (Curcumin longa L.) được pha trong dung môi DMSO (Sigma Aldrich, Pháp). Các hóa chất khác dùng trong nuôi cấy do Invitrogen cung cấp, ALDEFLUORTM Kit được cung cấp bởi STEMCELL technologies.

\subsection{Phân tích tăng sinh của tế bào bằng sàng lọc MTT}

Tế bào ung thư dạ dày MKN45 (5.000 tế bào) được nuôi cấy trong đĩa 96 giếng, trong môi

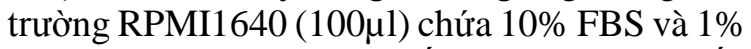
Penicillin/Streptomycin. Tế bào được nuôi cấy trong tủ ấm chuyên dụng ở nhiệt độ $37^{\circ} \mathrm{C}, 5 \%$ $\mathrm{CO}_{2}$. Sau khi các tế bào đã bám dính trên bề mặt đĩa nuôi cấy, tiến hành xử lý với curcumin ở các nồng độ từ $0-20 \mu \mathrm{M}$ curcumin trong 24 giờ và 48 giờ. Loại bỏ môi trường cũ, thay thế bằng môi trường RPMI1640 mới sau đó bổ sung thêm $20 \mu \mathrm{l}$ dung dịch MTT và ủ ở $37^{\circ} \mathrm{C}$ trong 4 giờ. Tiếp theo, loại bỏ hoàn toàn môi trường và được thay thế bằng dung môi DMSO $(100 \mu \mathrm{l})$ và tiếp tục ủ 15 phút ở $37^{\circ} \mathrm{C}$. Mật độ quang của mỗi giếng được đo bằng máy quang phổ Multiskan Sky ở bước sóng $570 \mathrm{~nm}$. Tỷ lệ phần trăm tế bào sống so với đối chứng được tính theo công thức: 
\% tế bào sống so với đối chứng = (Mật độ quang giếng xử lý/Mật độ quang giếng đối chứng)*100. Mỗi nồng độ được xử lý có số lần lặp lại $n=5$ (5 giếng cho một nồng độ).

Các tế bào trước khi phân tích MTT được chụp ảnh dưới kính hiển vi soi ngược TS2 (NIKON, Nhật Bản) ở độ phóng đại 200 và 400 lần.

\subsection{Phân tích apoptosis bằng Flow cytometry và hình thái nhân tế bào}

Phân tích apoptosis của tế bào được thực hiện theo phương pháp của Riccardi và Nicoletti [7]. Mô tả tóm tắt gồm: $2 \times 10^{5}$ tế bào được nuôi cây trên đĩa loại 12 giếng. Sau 24 giờ, tế bào được xử lý bằng môi trường nuôi cấy chứa curcumin ở các nồng độ khác nhau. Các giếng đối chứng không được xử lý với curcumin, trong 48 giờ trong điều kiện nuôi cấy ở $37^{\circ} \mathrm{C}, 5 \% \mathrm{CO}_{2}$. Tiếp theo, các tế bào được thu nhận bằng cách xử lý với trysin/EDTA và ly tâm 1.300 vòng/phút trong 3 phút. Sau đó, tế bào được nhuộm với dung dịch Fluorochrom $(0,1 \%$ sodium citrate (wt/v); 0,1\% Triton X-100 (v/v), $50 \mathrm{mg} / \mathrm{l}$ propidium iodide $(\mathrm{PI})$ ) trong thời gian $2 \mathrm{~h}$ ở $4^{0} \mathrm{C}$ trước khi phân tích bằng hệ thống dòng tế bào BD-Canto II (Biosciences, Mỹ). Kết quả dữ liệu được phân tích bằng phần mềm $\mathrm{BD}$ FACS Diva 6.1.1.

Kiểu hình tế bào apoptosis được phân tích bằng phương pháp nhuộm DAPI và chụp ảnh dưới kính hiển vi huỳnh quang. Mô tả tóm tắt gồm: các tế bào sau khi xử lý với curcumin ở các nồng độ khác nhau trong 48 giờ sẽ được cố định bằng Formaldehyde $3 \%$ trong 5 phút và sau đó được nhuộm với thuốc nhuộm DAPI nồng độ 10 $\mu \mathrm{g} / \mathrm{ml}$ DAPI trong 10 phút. Tế bào được rửa 2 lần với đệm $\mathrm{PBS} 1 \mathrm{X}$ và được chụp ảnh dưới kính hiển vi huỳnh quang T2U (NIKON, Nhật bản) ở độ phóng đại 200 và 400 lần ở kênh mầu dành cho thuốc nhuộm DAPI.

\subsection{Phân tích sự biểu hiện của ALDH bằng kỹ thuật miễn dịch huỳnh quang}

Các tế bào sau nuôi cấy được thu nhận bằng li tâm ở tốc độ 1.300 vòng trong 3 phút và rửa 2 lần với đệm PBS $1 X$. Phân tích sự biểu hiện của marker ALDH bằng cách sử dụng bộ kit
ALDEFLUOR (do Stem cell technology Canada cung cấp) theo hướng dẫn của nhà sản xuất. Tóm tắt các bước: tế bào được ủ với cơ chất của

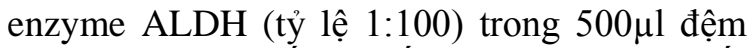
ALDEFLUOR. Đối với tế bào sử dụng làm đối chứng âm sẽ được bổ sung thêm DEAB - chất ức chế đặc hiệu của enzyme ALDH1. Sau đó, tế bào được ủ trong thời gian 20 phút ở $37^{\circ} \mathrm{C}$, sau đó tế bào được rửa 2 lần bằng đệm $\mathrm{ALDEFLUOR}$

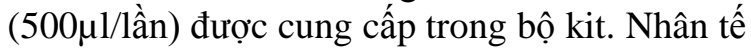
bào được nhuộm với $10 \mu \mathrm{g} / \mathrm{ml}$ DAPI trong đệm ALDEFLUOR ở lần rửa thứ 2 .

Các tế bào được nhuộm với cơ chất của enzyme ALDH trong bộ ALDEFLUOR sẽ được chụp ảnh dưới kính hiển vi huỳnh quang T2U (NIKON, Nhật Bản) ở độ phóng đại 200 lần và 400 lần với phần mềm chuyên dụng. Sử dụng khối phim lọc FITC để thu tín hiệu cho đánh dấu tế bào với ALDH. Sử dụng camera đơn sắc (monochrome) độ phân giải 4900 x 3260 pixels, nguồn kích thích huỳnh quang thủy ngân (Mercurry). Tất cả các mẫu đo (gồm đối chứng và xử lý) điều được đo ở cùng một điều kiện về cường độ kích thích huỳnh quang, độ phóng đại và thời gian phơi sáng để đảm bảo cho sự so sánh.

Toàn bộ các dữ liệu nghiên cứu được phân tích bằng phần mềm Grapad Prism 5.0, theo kiểm định Mann-Whitney U test.

\section{Kết quả và thảo luận}

\subsection{Curcumin ức chế sư tăng sinh và gây chết tế bào ung thu}

Kết quả phân tích tác động của curcumin lên kiểu hình và sự tăng sinh tế bào được thể hiện trong Hình 1 . Hình ảnh hiển vi của tế bào được xử lý với curcumin và tế bào đối chứng (không được xử lý với curcumin) trong Hình $1 \mathrm{~A}$ cho thấy, mật độ tế bào trong trường hợp xử lý với $5 \mu \mathrm{M}$ curcumin không có sự thay đổi so với nhóm đối chứng ở cả 2 mốc thời gian xử lý là 24 giờ và 48 giờ. Khi nồng độ curcumin tăng lên $10 \mu \mathrm{M}$ đã cho thấy mật độ tế bào bị xử lý đã bị giảm đi rõ rệt so với đối chứng. Ở nồng độ $10 \mu \mathrm{M}$, curcumin có rất ít các tế bào chết được quan sát sau 24 giờ xử lý, tuy nhiên, kiểu hình tế bào chết 
đã tăng lên rõ rệt khi thời gian xử lý tăng lên 48 giờ. Ở nồng độ cao $20 \mu \mathrm{M}$ của curcumin, hầu hết các tế bào đã bị chết ngay cả ở 24 giờ xử lý. Các tế bào chết bị biến đổi về hình thái màng và chất nguyên sinh, tế bào co nhỏ về kích thước và mất khả năng bám dính trên bề mặt đĩa nuôi cấy.

\section{A}
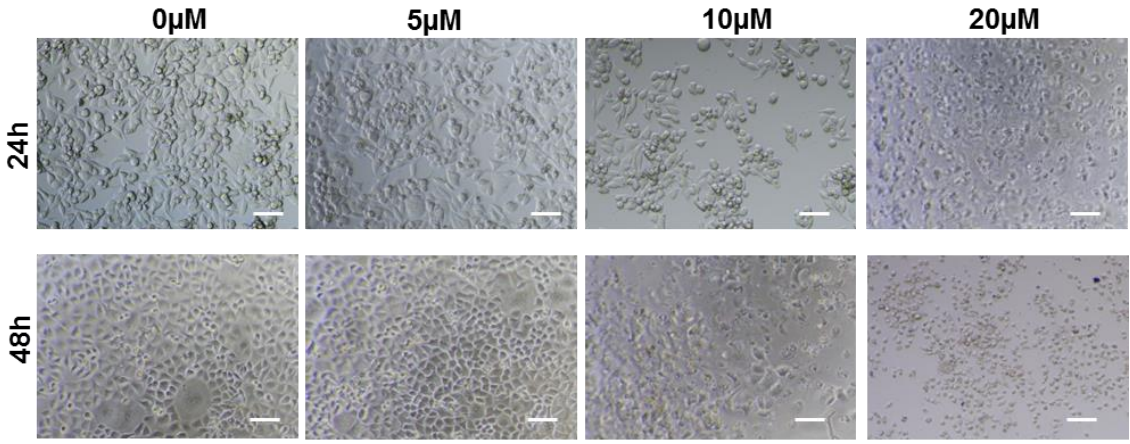

B

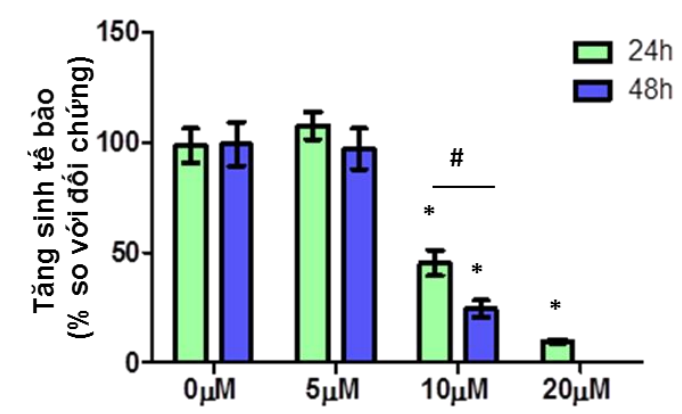

Hình 1. Ảnh hưởng của curcumin lên hình thái (A) và sự tăng sinh (B) của tế bào ung thư dạ dày MNK45, $\mathrm{n}=5,{ }^{*} \mathrm{p} \leq 0,0001$ so với đối chứng $(0 \mu \mathrm{M}), \# \mathrm{p} \leq 0,05$ (so sánh tác động của curcumin ở cùng nồng độ $10 \mu \mathrm{M}$ trong 24 giờ (h)với 48 giờ). Thang đo $50 \mu \mathrm{m}$.

Kết quả phân tích sự tăng sinh bằng phương pháp sàng lọc MTT trình bày trong Hình 1B đã khẳng định không có sự khác biệt về mật độ tế bào giữa đối chứng và nồng độ xử lý $5 \mu \mathrm{M}$. Ở nồng độ $10 \mu \mathrm{M}$, curcumin đã ức chế từ khoảng $50 \%$ (sau 24 giờ xử lý) đến $75 \%$ (sau 48 giờ xử lý). Chỉ còn khoảng $10 \%$ tế bào sống sót so với đối chứng được quan sát trong trường hợp tế bào được xử lý với curcumin ở nồng độ cao $20 \mu \mathrm{M}$ trong 24 giờ. Đặc biệt, toàn bộ các tế bào đã bị chết sau 48 giờ xử lý với curcumin ở nồng độ cao $20 \mu \mathrm{M}$. Các nghiên cứu trước đó của Heng Xu và cộng sự [8] trên 2 dòng tế bào ung thư dạ dày SGC-7901 và MKN28 cho thấy curcumin ở các nồng độ từ $5-20 \mu \mathrm{M}$ đã giảm tốc độ tăng sinh của tế bào từ 10 - 40\% so với đối chứng (không xử lý với curcumin). Trong một nghiên cứu khác của Zheng và cộng sự [9] đã cho thấy rằng, curcumin ở nồng độ từ $4-32 \mu \mathrm{M}$ có thể ức chế từ $20-80 \%$ tế bào ung thư dạ dày SNU-1, SNU5 và $A G S$ sau 24 giờ và 48 giờ xử lý. Như vậy có thể thấy rằng, curcumin có thể ức chế nhiều dòng tế bào ung thư dạ dày khác nhau, mức độ ức chế phụ thuộc vào nồng độ, thời gian xử lý và dòng tế bào. Trong nghiên cứu này của chúng tôi đã cho thấy, MKN45 rất nhạy cảm với việc xử lý bằng curcumin so với các dòng tế bào ung thư dạ dày khác đã được nghiên cứu. Các tế bào đã chết hoàn toàn chỉ sau 48 giờ xử lý với curcumin ở nồng độ $20 \mu \mathrm{M}$. 


\subsection{Curcumin cảm úng apoptosis tế bào ung thu dạ dày MKN45}

Để đánh giá tác động của curcumin lên sự cảm ứng quá trình apoptosis của tế bào MKN45, các tế bào sau khi được xử lý với curcumin ở các nồng độ khác nhau đã được phân tích bằng phương pháp Flow cytometry sử dụng thuốc nhuộm nhận PI. Kết quả phân tích được chỉ ra trong Hình $2 \mathrm{~A}$ và Hình $2 \mathrm{~B}$ cho thấy rằng, curcumin ở các nồng độ từ $10-20 \mu \mathrm{M}$ sau 48 giờ đã làm tăng tỷ lệ tế bào apoptosis lên từ 27 - 56\% so với đối chứng khoảng $2,5 \%$. Ở nồng độ xử lý $5 \mu \mathrm{M}$, không có sự khác biệt về tỷ lệ tế bào apoptosis so với đối chứng được chỉ ra. Hình ảnh phân tích Flow cytometry Hình $2 \mathrm{~A}$ cũng đã chỉ rõ một quần thể phụ (sub G0/G1) gồm các tế bào có kiểu hình apoptosis nằm tách rời khỏi các tế bào có kiểu hình bình thường của chu kỳ phân bào. Phân tích hình thái nhân tế bào với thuốc nhuộm DAPI trong Hình $2 \mathrm{C}$ một lần nữa cho thấy, ở nồng độ thấp $(5 \mu \mathrm{M})$, curcumin không làm xuất hiện các tế bào có kiểu nhân của tế bào apoptosis, tất cả các tế bào đều có nhân với một sự đồng đều về hình thái, kích thước tương tự như ở tế bào không xử lý với curcumin. Ở nồng độ $10 \mu \mathrm{M}$, curcumin đã làm xuất hiện các tế bào có kiểu nhân đặc trưng của tế bào apoptosis, nhân tế bào bị phân mảnh và tạo ra những đốm nhỏ bắt mầu rõ rệt với thuốc nhuộm DAPI. Tỷ lệ các tế bào có kiểu nhân apoptosis được tăng lên rõ rệt khi tế bào được xử lý với curcumin ở nồng độ cao hơn $(20 \mu \mathrm{M})$. Nghiên cứu trước đó của Heng Xu và cộng sự đã cho thấy, curcumin có khả năng gây apoptosis đối với dòng tế bào ung thư dạ dày SGC-7901. Cụ thể là ở nồng độ từ 5 $30 \mu \mathrm{M}$, curcumin đã làm tăng tỷ lệ tế bào apoptosis lên 11,36 - 59,09\% so với đối chứng là 2,23\% sau 48 giờ xử lý [8]. Trong một phân tích khác của Zheng và cộng sự, tỷ lệ apoptosis của tế bào SNU-1 đã tăng từ $18,1-42,8 \%$ khi bị xử lý với curcumin ở nồng độ từ $8-32 \mu \mathrm{M}$. Tương tự như vậy, nhóm nghiên cứu này cũng đã xác định được curcumin đã làm tăng rõ rệt tỷ lệ tế bào apoptosis ở các dòng tế bào ung thư dạ dày khác là SNU-5 và AGS [9]. Như vậy có thể thấy rằng, curcumin là một hợp chất có khả năng cảm ứng sự chết tế bào theo chương trình (apoptosis) ở nhiều dòng tế bào ung thư dạ dày khác nhau. Khả năng gây apoptosis tế bào có ý nghĩa đặc biệt quan trọng trong việc phát triển các thuốc chống ung thư hiện nay. Tế bào ung thư khi đi vào quá trình chết apoptosis sẽ dẫn tới sự phá hủy DNA nhân tế bào và cuối cùng là làm mất khả năng phân chia, tăng sinh khối u [13].

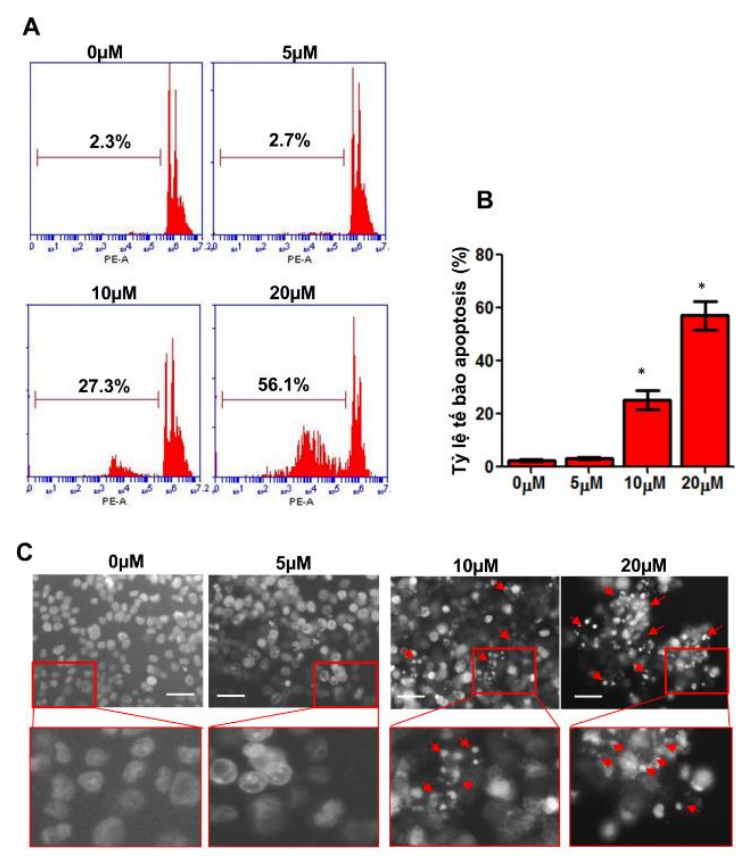

Hình 2. Ảnh hưởng của curcumin lên apoptosis của tế bào ung thư dạ dày MKN45 sau 48 giờ xử lý. Tỷ

lệ tế bào apoptosis được phân tích bằng Flow cytometry $(\mathrm{A}, \mathrm{B})$; Sự thay đồi kiểu hình của nhân tế bào, mũi tên chỉ kiểu nhân apoptosis, $n=5, * p \leq$ 0,0001 so với đối chứng $(0 \mu \mathrm{M})$. Thang đo: $50 \mu \mathrm{m}$.

\subsection{Curcumin điều hòa giảm sụ biểu hiện marker ALDH}

Trong nghiên cứu này, tác động của curcumin lên sự biểu hiện của protein ALDH cũng đã được phân tích bằng kỹ thuật nhuộm huỳnh quang (Hình 3 ). Cũng tương tự như các phân tích về sự tăng sinh và apoptosis tế bào, trong trường hợp tế bào không được xử lý với curcumin hoặc xử lý với curcumin ở nồng độ thấp $(5 \mu \mathrm{M})$, có một tỷ lệ khoảng $30 \%$ các tế bào biểu hiện hoạt tính của enzyme ALDH (mầu xanh). Tỷ lệ các tế bào này được quan sát là giảm đi rất rõ rệt trong các trường hợp tế bào MKN45 
bị xử lý với curcumin ở nồng độ $10 \mu \mathrm{M}$. Đáng chú ý, ở nồng độ $20 \mu \mathrm{M}$ đã không còn tế bào nào biểu hiện ALDH được quan sát thấy. Như vậy có thể thấy rằng, tỷ lệ biểu hiện ALDH tỷ lệ nghịch với tỷ lệ apoptosis trong quần thể tế bào ung thư dạ dày MKN45. Sự tương quan này cũng đã được chúng tôi chỉ ra trước đó trong một nghiên cứu sử dụng Altrans retinoic acid nhắm đích tế bào ung thư ở các dòng tế bào ung thư dạ dày và các tế bào ung thư phân lập trực tiếp từ khối u của bệnh nhân ung thư dạ dày [14].

ALDH được biến đến như là những enzyme có chức năng oxy hóa aldehyde thành carboxylic acid. Quá trình oxi hóa nhóm aldehyde là thiết yếu trong sự giải độc tế bào khỏi các ảnh hưởng có hại của các aldehyde. Bên cạnh đó, một số sản phẩm được tạo bởi quá trình oxi hóa này rất quan trọng đối với quá trình phân chia, biệt hóa cũng như phát triển của tế bào [14]. Trước đó, chúng tôi cũng đã chỉ ra rằng, $\mathrm{ALDH}$ làm một marker của tế bào gốc ung thư dạ dày, sự biểu hiện maker ALDH trong tế bào ung thư dạ dày liên quan chặt chẽ đến sự kháng thuốc và đào thải các thuốc nhuộm Hoesch ra khỏi tế bào, giúp bảo vệ tế bào ung thư [13]. Đã có những bằng chứng cho thấy, ức chế sự biểu hiện của enzyme ALDH bằng các phương pháp khác nhau như sử dụng các chất ức chế tồng hợp, các oligo antisense và các siRNA đã là giảm rõ rệt sự tăng sinh của tế bào [15]. Trong một nghiên cứu trên ung thư lympho bào Hodgkin, mức độ biểu hiện cao của ALDH và biểu hiện thấp các gốc oxy hóa tự do (ROS) đã được tìm thây trong các tế bào khởi nguồn (tế bào gốc ung thư) của loại ung thư này. ROS đã được biết rất rõ như là yếu tố đặc biệt quan trọng liên quan tới sự cảm ứng apoptosis tế bào [16]. Như vậy có thể thấy rằng, ALDH đóng vai trò quan trọng trong việc đào thải độc tố và giảm các gốc oxy hóa tự do dẫn tới ngăn cản quá trình apoptosis trong tế bào ung thư. Trong nghiên cứu này, chúng tôi đã chỉ ra được curcumin đã điều hòa giảm số lượng tế bào biểu hiện enzyme ALDH. Tỷ lệ các tế bào apoptosis tỷ lệ nghịch với các tế bào biểu hiện enzyme ALDH.

A
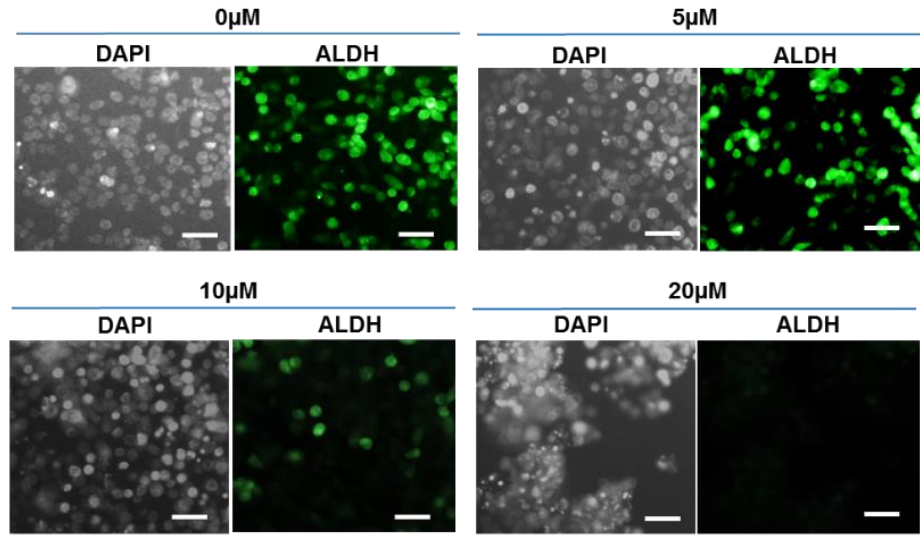

B

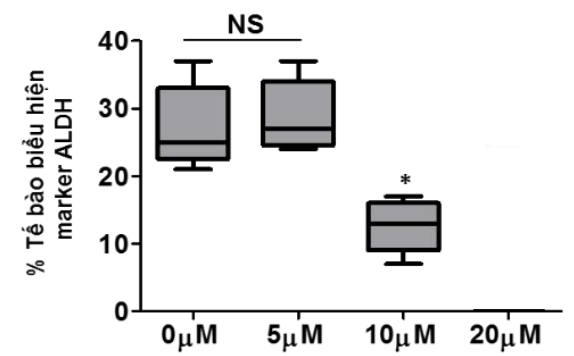

Hình 3. Ảnh hưởng của curcumin lên sự biểu hiện ALDH của tế bào ung thư dạ dày MKN45, $\mathrm{n}=5, \mathrm{NS}$ : không khác biệt; *p $\leq 0,0001$ so với đối chứng $(0 \mu \mathrm{M})$. Thang đo: $50 \mu \mathrm{m}$. 


\section{Kết luận}

Trong nghiên cứu này, chúng tôi đã chỉ ra rằng, curcumin có nguồn gốc từ cây Nghệ (Curcumin longa) có khả năng ức chế hiệu quả sự tăng sinh của tế bào ung thư dạ dày MKN45. Ở nồng độ từ $10 \mu \mathrm{M}$, curcumin đã cảm ứng quá trình apoptosis của tế bào. Đặc biệt, curcumin đã làm giảm rõ rệt sự biểu hiện của enzyme ALDH - một enzyme đóng vai trò quan trọng trong quá trình đào thải độc tố, giảm thiểu các gốc oxy hóa tự do trong tế bào, ngăn cản quá trình apoptosis trong các tế bào ung thư.

\section{Tài liệu tham khảo}

[1] P. Rawla, A. Barsouk, Epidemiology of gastric cancer: global trends, risk factors and prevention, Pg 14 (2019) 26-38. https://doi.org/10.5114/pg. 2018.80001.

[2] A. Lichota, K. Gwozdzinski, Anticancer Activity of Natural Compounds from Plant and Marine Environment, Int J Mol Sci 19 (2018). https://doi.org/10.3390/ijms19113533.

[3] A. Giordano, G. Tommonaro, Curcumin and Cancer, Nutrients 11 (2019). https://doi.org/10. 3390/nu11102376.

[4] W. Yim-im, O. Sawatdichaikul, S. Semsri, N. Horata, W. Mokmak, S. Tongsima, et al, Computational analyses of curcuminoid analogs against kinase domain of HER2, BMC Bioinformatics 15 (2014) 261. https://doi.org/10. 1186/1471-2105-15-261.

[5] S. Lev-Ari, A. Starr, A. Vexler, V. Karaush, V. Loew, J. Greif, et al, Inhibition of pancreatic and lung adenocarcinoma cell survival by curcumin is associated with increased apoptosis, down-regulation of COX-2 and EGFR and inhibition of Erk1/2 activity, Anticancer Res 26 (2006) 4423-30.

[6] C.W. Yang, C.L. Chang, H.C. Lee, C.W. Chi, J.P. Pan, W.C. Yang, Curcumin induces the apoptosis of human monocytic leukemia THP-1 cells via the activation of JNK/ERK pathways, BMC Complement Altern Med (2012) 12 - 22.

[7] K. Wang, H. Fan, Q. Chen, G. Ma, M. Zhu, X. Zhang, et al, Curcumin inhibits aerobic glycolysis and induces mitochondrial-mediated apoptosis through hexokinase II in human colorectal cancer cells in vitro, Anticancer Drugs 26 (2015) 15-24. https://doi.org/10.1097/CAD.0000000000000132.
[8] T. Hassanalilou, S. Ghavamzadeh, L. Khalili, Curcumin and Gastric Cancer: a Review on Mechanisms of Action, J Gastrointest Cancer 50 (2019) 185-92. https://doi.org/10.1007/s12029018-00186-6.

[9] G. Liu, T. Xiang, Q.F. Wu, W.X. Wang, Curcumin suppresses the proliferation of gastric cancer cells by downregulating H19, Oncol Lett 12 (2016) 5156-62. https://doi.org/10.3892/ol. 2016.5354.

[10] R. Zheng, Q. Deng, Y. Liu, P. Zhao, Curcumin Inhibits Gastric Carcinoma Cell Growth and Induces Apoptosis by Suppressing the Wnt/ $\beta$ Catenin Signaling Pathway, Med Sci Monit 23 (2017) 163-71. https://doi.org/10.12659/msm. 902711.

[11] G. Muzio, M. Maggiora, E. Paiuzzi, M. Oraldi, R.A. Canuto, Aldehyde dehydrogenases and cell proliferation, Free Radic Biol Med 52 (2012) 735-46. https://doi.org/10.1016/j.freeradbiomed. 2011.11.033.

[12] C. Riccardi, I. Nicoletti, Analysis of apoptosis by propidium iodide staining and flow cytometry, Nat Protoc 1 (2006) 1458-61. https://doi.org/10. 1038/nprot.2006.238.

[13] Y. Fuchs, H. Steller, Programmed cell death in animal development and disease, Cell 147 (2011) 742-58.https://doi.org/10.1016/j.cell.2011. 10.033.

[14] P.H. Nguyen, J. Giraud, C. Staedel, L. Chambonnier, P. Dubus, E. Chevret, et al, Alltrans retinoic acid targets gastric cancer stem cells and inhibits patient-derived gastric carcinoma tumor growth, Oncogene 35 (2016) 5619-28. https://doi.org/10.1038/onc.2016.87.

[15] V. Vasiliou, D.C. Thompson, C. Smith, M. Fujita, Y. Chen, Aldehyde dehydrogenases: from eye crystallins to metabolic disease and cancer stem cells, Chem Biol Interact 202 (2013) 2-10. https://doi.org/10.1016/j.cbi.2012.10.026.

[16] P.H. Nguyen, J. Giraud, L. Chambonnier, P. Dubus, L. Wittkop, G. Belleannée, et al, Characterization of Biomarkers of Tumorigenic and Chemoresistant Cancer Stem Cells in Human Gastric Carcinoma, Clin Cancer Res 23 (2017) 1586-97.https://doi.org/10.1158/1078-0432. CCR -15-2157.

[17] J. Ikeda, S. Mamat, T. Tian, Y. Wang, W. Luo, N. Rahadiani, et al, Reactive oxygen species and aldehyde dehydrogenase activity in Hodgkin lymphoma cells, Lab Invest 92 (2012) 606-14. https://doi.org/10.1038/labinvest.2012.4. 